Acta Protozool. (2016) 55: 239-248

www.ejournals.eu/Acta-Protozoologica

doi:10.4467/16890027AP.16.026.6095

PROTOZOOLOGICA

\title{
Molecular Phylogeny of the Marine Planktonic Dinoflagellate Oxytoxum and Corythodinium (Peridiniales, Dinophyceae)
}

\author{
Fernando GÓMEZ ${ }^{1}$, Kevin C. WAKEMAN ${ }^{2, a}$, Aika YAMAGUCHI ${ }^{3}$, Hisayoshi NOZAKI ${ }^{4}$ \\ ${ }^{1}$ Carmen Campos Panisse 3, Puerto de Santa María, Spain; ${ }^{2}$ Komaba International Building for Education and Research (KIBER), \\ University of Tokyo, Tokyo, Japan; ${ }^{3}$ Kobe University Research Center for Inland Seas, Kobe, Japan; ${ }^{4}$ Department of Biological

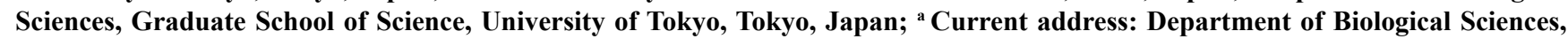 \\ Faculty of Science, Hokkaido University, Sapporo, Japan
}

\begin{abstract}
The dinoflagellate genera Oxytoxum and Corythodinium that account for more than fifty species are widespread in warm oceans. These genera have been considered synonyms and thecal plate designations varied among authors. Several planktonic and sand-dwelling genera have been placed within the Oxytoxaceae. We obtained the first molecular data based on small subunit (SSU) rRNA gene sequences of Oxytoxum and Corythodinium, including the type species (O. scolopax and C. tessellatum) and C. frenguellii and C. cristatum. The three species of Corythodinium branched together a strong support [bootstrap (BP) of 98\%]. This formed a sister clade with moderate support (BP 75\%) with O. scolopax that supported the generic split. Oxytoxaceae should exclusively remain for Oxytoxum and Corythodinium, as an independent group, unrelated to any other known dinoflagellate. Oxytoxum was characterized by spindle-shaped cells with an anterior narrow epitheca, an apical spine and little cingular displacement. Corythodinium exhibits relatively broad cell shapes, with wider epitheca and greater cingular displacement, and an obovate or pentangular anterior sulcal plate that noticeably indented the epitheca. This suggested the need of new combinations for species that were described as Oxytoxum and possessed the characteristics of Corythodinium.
\end{abstract}

Key words: $18 \mathrm{~S}$ ribosomal RNA, armored Dinophyta, Atlantic Ocean, Mediterranean Sea, phytoplankton, SSU rDNA phylogeny, taxonomy, thecate Dinoflagellata.

\section{INTRODUCTION}

The genera Oxytoxum and Corythodinium account for more than fifty species, most often reported in the phytoplankton assemblages of warm temperate and tropical seas (Kofoid 1907, Schiller 1937; Rampi 1939, 1941, 1951; Gaarder 1954; Balech 1954, 1971a,b; Tay-

\footnotetext{
Address for correspondence: Fernando Gómez, Carmen Campos Panisse 3, E-11500 Puerto de Santa María, Spain; E-mail: fernando. gomez@fitoplancton.com
}

lor 1976, Gómez et al. 2008). The genera Oxytoxum and Pyrgidium were described by Stein (1883) having five postcingular plates and the first one (1"') being shorter and narrower than the others. He proposed Oxytoxum for four elongated species with a pointed apex and antapex or spines, and Pyrgidium for broader cells with more blunt ends. However, the generic split was not clear cut and further authors merged both genera into Oxytoxum (Schiller 1937). Based on plate dissections, Balech (1954, p. 115) reported the tabulation of $O$. constrictum as 3', 2a, 6", 5c, 4-5s, 5',' 1',', and Oxytoxum scolopax as 3', 2a, 3', 5c, 4-5s, 5 ', 1 '”,'. Unfortunately, there 
was an error in the plate formula that was reported as 3 " instead of 6". Loeblich and Loeblich (1966) noted that Pyrgidium was a posterior homonym of the lichen Pyrgidium Nylander, and without making new observations they proposed the name Corythodinium. Oxytoxum scolopax and Corythodinium tessellatum, stand as type species for their respective genera.

Taylor (1976) amended the diagnosis of Corythodini$u m$ and supported the generic split, due to 1) the presence of a large obovate or pentagular anterior sulcal region that deeply invades the epitheca in Corythodinium, whereas the anterior sulcal plate of Oxytoxum only slightly invades the epitheca, 2) Corythodinium possesses a high, left-handed cingular displacement, while the cingular displacement is low in Oxytoxum, and 3) members of Oxytoxum possess a relatively small epitheca, compared to the relatively large epitheca found in Corythodinium (Taylor 1976). Sournia (1986) maintained the split of Oxytoxum and Corythodinium, and reported the tabulation Po, 3', 2a, 3", 5c, 4-5s, 5'”, 1 '”' for Oxytoxum, and ?Po, 3', 2a, 6", 5c, ?s, 5'”, 1 '”' for Corythodinium. The presence of only three precingular plates (3") in Oxytoxum could be explained as a mistake in Balech (1954, p. 116). Balech (1988) also maintained the split between Corythodinium and Oxytoxum. Steidinger and Tangen (1997) reported the plate formula Po, 5', 6”, 5c, 4s, 5",' 1 '”' for Oxytoxum and Po, 3', 2a, 6", 5c, ?4s, 5 ", 1 ,"” for Corythodinium. Taylor (1976, his figure 512) carried out the first SEM study. He showed the ventral cingular area of $O$. scolopax. More complete studies were reported by Burns and Mitchell (1982) and Dodge and Saunders (1985). The latter authors proposed the plate formula Po, 5', 6”, 5c, 4s, 5 '”, 1 '”' and re-established Corythodinium as a synonym of Oxytoxum (Dodge and Saunders 1985). Fensome et al. (1993) also considered Corythodinium as a synonym of Oxytoxum.

The variability in the synonymy and the plate arrangement of Oxytoxum and Corythodinium is also accompanied with differences in the classification. These genera have been placed within the family Oxytoxaceae together with other planktonic genera such as Centrodinium and Schuettiella, and the sand-dwelling genera Amphidiniopsis, Planodinium, Pseudadenoides (formerly Adenoides), Roscoffia, Sabulodinium and Thecadinium (Loeblich 1982, Dodge 1984, Sournia 1986, Taylor 1987, Chrétiennot-Dinet et al. 1993, Fensome et al. 1993, Steidinger and Tangen 1997). The family Oxytoxaceae has been placed within the order Gonyaulacales (Taylor 1987, Steidinger and Tangen 1997) or as an uncertain order within the subclass Peridiniphycidae (Fensome et al. 1993).
Currently, there is no molecular data representing Oxytoxum and Corythodinium, despite both genera being represented with the combined descriptions of more than fifty species, and being widely distributed. The lack of molecular data hinders the ability to solve the discrepancies in the synonymy and classification among members of the Oxytoxaceae. In this study, we provide the first molecular data representing the type species of Oxytoxum and Corythodinium, as well as additional sequences of other two species.

\section{MATERIALS AND METHODS}

\section{Sampling and microscopy}

Cells of Oxytoxum and Corythodinium were observed from water samples collected at four coastal sites in the north-western Mediterranean Sea (Marseille, Banyuls sur Mer, Villefranche sur Mer, Valencia), and open-water stations in the Mediterranean Sea, as reported in Gómez et al. (2016), and the Appendix S1 in the Supporting Information. In the South Atlantic Ocean, sampling continued after March 2013 in São Sebastião Channel (23 $50^{\prime} 4.05^{\prime \prime}$, $\left.45^{\circ} 24^{\prime} 28.82^{\prime \prime} \mathrm{W}\right)$, and from December 2013 to December 2015 off Ubatuba $\left(23^{\circ} 32^{\prime} 20.15^{\prime \prime} \mathrm{S}, 45^{\circ} 5^{\prime} 58.94^{\prime \prime} \mathrm{W}\right)$. The Brazilian cells were obtained using a phytoplankton net $(20 \mu \mathrm{m}$ mesh size $)$ in surface waters. The living concentrated samples were examined in Utermöhl chambers at magnification of $\times 200$ with inverted microscopes (Diaphot-300, Nikon Inc. at São Sebastião, and Eclipse TS-100, Nikon Inc. and Olympus IX73, Olympus Inc. at Ubatuba), and photographed with a digital camera (Cyber-shot DSC-W300, Sony, Tokyo, Japan) mounted on the microscope's eyepiece. Cells of $O$. scolopax from Brazil that showed higher pigmentation were isolated with the aim to establish cultures. Individuals were isolated using a micropipette and placed in 12-well tissue culture plate with $0.2 \mu \mathrm{m}$-filtered seawater collected that day from the same locality, and they were supplemented with $\mathrm{f} / 2$ medium without silicates. Two days later, the healthy cells were re-isolated and placed into a 6-well tissue culture plate with $\mathrm{f} / 2$ medium made with filtered and sterilized seawater. The culture plates were placed in an incubator used for microalgae culturing, at $23^{\circ} \mathrm{C}, 100 \mu \mathrm{mol}$ photons $\cdot \mathrm{m}^{-2} \mathrm{~s}^{-1}$ from cool-white tubes and photoperiod 12:12 L:D.

In addition to the coastal sampling, a net sample was collected in the open South Atlantic on June 23, 2015 (25 $32^{\prime} 43.8^{\prime \prime} \mathrm{S}$; $44^{\circ} 57^{\prime} 52.4^{\prime \prime} \mathrm{W}$, bottom depth of $\left.1000 \mathrm{~m}\right)$. The sample was collected in a vertical haul with a phytoplankton net ( $20 \mu \mathrm{m}$ mesh size) from $500 \mathrm{~m}$ depth to the surface. The concentrate was transferred into a 500-ml plastic container and preserved with neutral Lugol's iodine. The sample was analyzed within 2 weeks.

\section{PCR amplification of small subunit rRNA gene, sequencing and phylogenetic analyses}

Novel sequences were obtained from cells collected in Brazil (Table 1). Each cell of Oxytoxum or Corythodinium was micropipetted individually with a fine capillary into a clean chamber and washed several times in serial drops of $0.2-\mu \mathrm{m}$ filtered and sterilized seawater. Finally, 1-5 cells of each species were deposited in a 0.2-ml Eppen- 
Table 1. List of sequences of Oxytoxum and Corythodinium.

\begin{tabular}{|c|c|c|c|c|c|c|c|}
\hline Taxa & GenBank no. & Sampling date & Geographic origin & $\begin{array}{l}\text { Bottom } \\
\text { depth }\end{array}$ & $\begin{array}{l}\text { Latitude } \\
\text { South }\end{array}$ & $\begin{array}{l}\text { Longitude } \\
\text { West }\end{array}$ & Figure \\
\hline O. scolopax FG11 & KY421376 & 7 Aug 2013 & São Sebastião Channel & $40 \mathrm{~m}$ & $23^{\circ} 50^{\prime} 4.05^{\prime \prime}$ & $45^{\circ} 24^{\prime} 28.82^{\prime \prime}$ & Fig. 2A \\
\hline O. scolopax FG43 & KY421375 & 1 Nov 2015 & off Ubatuba & $15 \mathrm{~m}$ & $23^{\circ} 32^{\prime} 20.15^{\prime \prime}$ & $45^{\circ} 5^{\prime} 58.94^{\prime \prime}$ & Fig. S1A \\
\hline C. tessellatum FG9 & KY421378 & 15 May 2013 & São Sebastião Channel & $40 \mathrm{~m}$ & $23^{\circ} 50^{\prime} 4.05^{\prime \prime}$ & $45^{\circ} 24^{\prime} 28.82^{\prime \prime}$ & Fig. $2 \mathrm{C}$ \\
\hline C. tessellatum FG40 & KY421377 & 22 Aug 2013 & São Sebastião Channel & $40 \mathrm{~m}$ & $23^{\circ} 50^{\prime} 4.05^{\prime \prime}$ & $45^{\circ} 24^{\prime} 28.82^{\prime \prime}$ & Fig. $2 \mathrm{H}$ \\
\hline C. tessellatum $\mathrm{FG} 42$ & KY421379 & 27 Nov 2015 & off Ubatuba & $15 \mathrm{~m}$ & $23^{\circ} 32^{\prime} 20.15^{\prime \prime}$ & $45^{\circ} 5^{\prime} 58.94^{\prime \prime}$ & Fig. S2, B-C \\
\hline C. frenguellii $\mathrm{FG} 7$ & KY421380 & 2 May 2013 & São Sebastião Channel & $40 \mathrm{~m}$ & $23^{\circ} 50^{\prime} 4.05^{\prime \prime}$ & $45^{\circ} 24^{\prime} 28.82^{\prime \prime}$ & Fig. 2K \\
\hline C. frenguellii FG8 & KY421382 & 13 Jun 2013 & São Sebastião Channel & $40 \mathrm{~m}$ & $23^{\circ} 50^{\prime} 4.05^{\prime \prime}$ & $45^{\circ} 24^{\prime} 28.82^{\prime \prime}$ & Fig. 2L \\
\hline C. frenguellii FG46 & KY421381 & 19 Jun 2015 & off Ubatuba & $15 \mathrm{~m}$ & $23^{\circ} 32^{\prime} 20.15^{\prime \prime}$ & $45^{\circ} 5^{\prime} 58.94^{\prime \prime}$ & Fig. S1D \\
\hline C. cristatum $\mathrm{FG} 28$ & KY421383 & 23 Jun 2015 & open South Atlantic & $1000 \mathrm{~m}$ & $25^{\circ} 32^{\prime} 43.8^{\prime \prime}$ & $44^{\circ} 57^{\prime} 52.4^{\prime \prime}$ & Fig. $2 \mathrm{M}-\mathrm{N}$ \\
\hline C. cristatum FG30 & KY421374 & 23 Jun 2015 & open South Atlantic & $1000 \mathrm{~m}$ & $25^{\circ} 32^{\prime} 43.8^{\prime \prime}$ & $44^{\circ} 57^{\prime} 52.4^{\prime \prime}$ & Fig. S1E-F \\
\hline
\end{tabular}

dorf tube filled with several drops of absolute ethanol. The sample was kept at room temperature and in darkness until the molecular analysis could be performed. Prior to DNA extraction, the 0.2-ml Eppendorf tubes were centrifuged for $10 \mathrm{~min}$ at $14462 \mathrm{~g}$ (TOMY MX201, Tokyo, Japan). Ethanol was then evaporated in a vacuum desiccator. Cells were resuspended in $10 \mu \mathrm{l}$ of QuickExtract FFPE DNA Extraction Kit (Epicenter Biotechnologies, Madison, WI, USA) and incubated at $56^{\circ} \mathrm{C}$ for $1 \mathrm{~h}$ and $98^{\circ} \mathrm{C}$ for $2 \mathrm{~min}$ in a thermal cycler (GeneAmp PCR System 9700, Applied Biosystems, Foster City, CA, USA). The extracted product $(1 \mu \mathrm{l})$ was used as DNA template for polymerase chain reaction (PCR). In order to amplify SSU rDNA, three rounds of PCR were performed. In the first round, the primers SR1 5'-TACCTGGTTGATCCTGCCAG-3' and SR12 5'-CCTTCCGCAGGTTCACCTAC-3' were used in a reaction with Econotaq (Lucigen, Middleton, WI, USA) and $1 \mu 1$ of extracted DNA. For this initial reaction, the following program was used on a thermocycler: Initial denaturation at $94^{\circ} \mathrm{C}$ for $2 \mathrm{~min} ; 35$ cycles of denaturation at $94^{\circ} \mathrm{C}$ for $30 \mathrm{~s}$, annealing at $52^{\circ} \mathrm{C}$ for $30 \mathrm{~s}$, and extension at $72^{\circ} \mathrm{C}$ for $2 \mathrm{~min}$; final extension at $72^{\circ} \mathrm{C}$ for $7 \mathrm{~min}$. In the second round of PCR, $1 \mu \mathrm{l}$ of the first PCR product was used as DNA template and the specific forward 5'-CGAACGAATCGCATGGCATCC-3' and reverse primers 5'-GGAACCGAACACTGCTTCAG-3', were paired with SR1 and SR12, respectively. PCR conditions for the second round of PCR was the same as the first, except that the cycling extension time was shortened to $1 \mathrm{~min} 20 \mathrm{~s}$. PCR products were directly sequenced using ABI PRISM BigDye Terminator Cycle Sequencing Kit (Applied Biosystems) and a DNA autosequencer ABI PRISM3100 Genetic Analyzer (Applied Biosystems).

The ten sequences generated in this study were aligned with MUSCLE (Edgar 2004) with 61 sequences representing a diverse set of dinokaryotic lineages; alignments were subsequently finetuned manually. Sequences of the basal dinoflagellate Hematodinium and Syndinium (GenBank accession numbers EF065717 and DQ146404) were used as an outgroup. Aligned sequences were examined using Maximum Likelihood (ML) analyses with Garli-GUI under a GTR $+\mathrm{I}+\Gamma$ model of evolution selected by JModelTest 2.1 .10 (proportion of invariable sites $=0.4289$, gamma shape $=0.3970$ ). Bootstrap analysis was calculated for 500 pseudoreplicates. Our sequences were deposited in DDBJ/EMBL/GenBank under accession numbers KY421374-KY421383 (Table 1).

\section{RESULTS}

\section{Morphology}

Oxytoxum and Corythodinium were occasionally encountered during the sampling between 2007 and 2011 along the Mediterranean coasts at Marseille, Banyuls sur Mer, Villefranche sur Mer and Valencia, and samples collected from the open Mediterranean Sea during the BOUM cruise in July 2008 (see Appendix S1 in the Supporting Information). The genera never reached high abundances, and when present, observations were restricted to a few cells per sample. In the open Mediterranean Sea, the highest abundances were sixteen cells $1^{-1}$ of $O$. scolopax and $O$. variabile, in the Gulf of Lions and south of Crete. Other species such as C.constrictum and $O$. sceptrum reached abundances of eight cells $1^{-1}$ in the open Mediterranean Sea. The most common species observed, while examining live cells along the Mediterranean coastal sites were $O$. scolopax (Figs $1 \mathrm{~A}-\mathrm{E}$ ) and $C$. constrictum (Figs $1 \mathrm{G}-\mathrm{H}$ ). Other, less frequently encountered species included $C$. tessellatum (Figs $1 \mathrm{~J}-\mathrm{L}$ ), C. reticulatum, C. diploconus, O. coronatum, O. cribrosum, O. sceptrum and $O$. crassum. Other species such as $C$. frenguellii (Fig. $1 \mathrm{M})$ and C. cristatum (Figs $1 \mathrm{~N}-\mathrm{O}$ ) were rare, especially the latter species that was only observed in the vertical hauls in the Bay of Villefranche sur Mer.

Oxytoxum scolopax is the most common species encountered within the genus. The cells were sharply elongated, spindle-shaped and measured 85-105 $\mu \mathrm{m}$ long and $12-17 \mu \mathrm{m}$ wide $(\mathrm{n}=24)$. The epitheca was triangular in outline, with a prominent apical spine. The cingulum was situated a quarter of the cell length from 


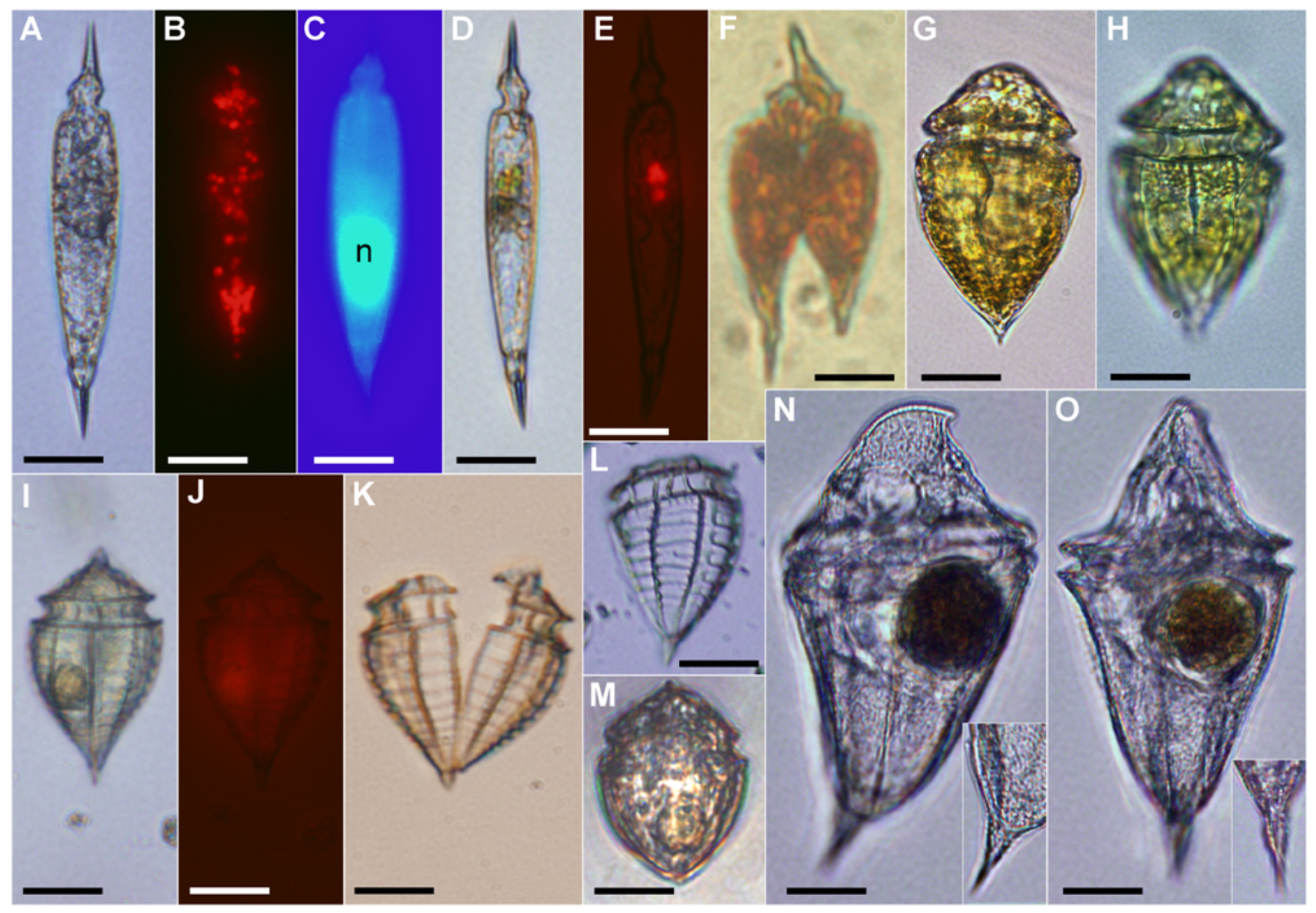

Figs 1A-O. Light micrographs of Oxytoxum and Corythodinium from the Mediterranean Sea. A-E - O. scolopax from Banyuls sur Mer. B-C, E, J - Epifluorescence microscopy. B, E, J - Note the autofluorescence of the chloroplasts. C - Nucleus stained by DAPI. F - Dividing cells of $O$. sceptrum. $\mathbf{G}-\mathbf{H}-C$. constrictum from Villefranche sur Mer. $\mathbf{I}-\mathbf{L}-C$. tessellatum from Banyuls sur Mer. $\mathbf{K}-\mathbf{L}-$ Empty thecae. $\mathbf{M}-$ C. frenguellii from Villefranche sur Mer. $\mathbf{N}-\mathbf{O}-$ C. cristatum from Villefranche sur Mer. The insets show the antapical spine. $\mathrm{n}$ - nucleus. Scale bars: $20 \mu \mathrm{m}$.

the anterior. The elongated hypotheca showed convex margins. The antapical spine showed a bladder-like swelling at the base (Figs 1A-E; 2A-B). The recently collected cells of $O$. scolopax were weakly covered with small and dispersed globular chloroplasts, as revealed by epifluorescence microscopy (Figs 1A-B). Other cells contained chloroplasts restricted to the middle of the hypotheca (Figs 1D-E). The nucleus was ellipsoidal and oriented along the anteroposterior axis, in the middle of the posterior half of the hypotheca (Fig. 1C). During the cell division of Oxytoxum, tentatively $O$. sceptrum, the dividing cells joined at the anterior half of the hypotheca. One daughter cell maintained the pointed antapex, formed by the first antapical plate of the mother cell, while the other daughter kept the apical spine (Fig. 1F). The species $C$. constric- tum (Figs 1G-H) usually appeared more pigmented than O. scolopax. Corythodinium tessellatum measured 50-60 $\mu \mathrm{m}$ long $(\mathrm{n}=26)$. The epitheca was wide and low, with a short apical spine. The hypotheca was slightly wider than the epitheca, with convex contour and a short antapical spine. In addition to the longitudinal ridges, the most distinctive feature of this species was the transversal tessellation of the hypotheca (Figs 1I-L). The cells were slightly pigmented, often restricted to a spherical structure in the hypotheca (Figs 1I-J). Corythodinium frenguellii was about $50 \mu \mathrm{m}$ long (Fig. 1M). When compared to C. tessellatum, the cells of $C$. frenguellii were more broad, without apical and antapical spines, with a more posterior cingulum and lacking the transversal tessellation that characterized C. tessellatum (Fig. 1L). Corythodinium cristatum was 
a large species $(115-120 \mu \mathrm{m}$ long, $60 \mu \mathrm{m}$ wide, $\mathrm{n}=2)$ with a laterally compressed cell body. The epitheca was helmet-shaped with a dorsally recurved apex. The hypotheca showed slightly convex margins, the dorsal margin broadly rounded and the ventral margin with a ventrally deflected antapical spine. The cells were hyaline, except with a dark-green granule located in the anterior half of the hypotheca (Figs $1 \mathrm{~N}-\mathrm{O}$ ).

Along the coasts of the São Paulo State in Brazil, the genera Oxytoxum and Corythodinium never reached high abundances. The most common species were O. scolopax (Figs 2A-B), C. tessellatum (Figs 2B-I), C. constrictum (Figs 2I-J), and more rarely $C$. frenguellii (Figs $2 \mathrm{~K}-\mathrm{L}$ ). The species $C$. cristatum was only observed in one sample collected from a vertical haul between $500 \mathrm{~m}$ depth and the surface (Figs 2M-N). As Oxytoxum (Fig. 1F), Corythodinium divided by desmoschisis (Figs $2 \mathrm{E}-\mathrm{H}, \mathrm{J}$ ). One daughter cell maintained the apical plates and lacked the pointed, first antapical plate. The other daughter cell had a relatively smaller epitheca and maintained the antapical spine, formed by the antapical plate (Figs 2E-H, J). We attempted to culture chloroplast-containing species of Oxytoxum and Corythodinium. However, the cells did not survive more than three days under laboratory conditions.

\section{Molecular phylogeny}

Two novel SSU rDNA sequences representing the type species of Oxytoxum, O. scolopax, were generated from cells collected at São Sebastião Channel in 2013 and off Ubatuba in 2015 (Figs 2A-B; S1A), three sequences representing the type species of Corythodinium, C. tessellatum, were also generated. Samples of C. tessellatum were also collected from different periods and locations (Figs 2C-H; S1B-C). Three sequences of C. frenguellii (Figs 2K-L; S1D) were obtained from cells collected from two different sites, and two sequences of $C$. cristatum (Figs $2 \mathrm{M}-\mathrm{N}$; S1E-F) were obtained from cells collected from a vertical haul from $500 \mathrm{~m}$ depth to the surface (Table 1). The sequence identity between the type species of the two genera, O. scolopax and C. tessellatum, was $97 \%$ across 1,654 base pairs of $18 \mathrm{~S}$ rDNA. We examined the phylogenetic position of Oxytoxum and Corythodinium using a dataset that included a variety of dinoflagellate SSU rDNA sequences with focus on Peridiniales, and including the genera that have been classified as members of the Oxytoxaceae (Amphidiniopsis, Pseudadenoides, Roscoffia, Sabulodinium and Thecadinium).
The analysis showed that Oxytoxum and Corythodinium sequences were subdivided into two clades that formed a monophyletic group with moderate support [(bootstrap (BP) of 75\%] in the maximum-likelihood phylogenetic tree (Fig. 3). One clade comprised the sequences of the three species of Corythodinium with a high support (BP, 98\%), while the second clade contained the sequences of $O$. scolopax (Fig. 3). Our data supported the splitting of Oxytoxum and Corythodinium into two distinct genera based on the evolutionary distance of their respective SSU rDNA sequences. Our new sequences did not show any particularly close affiliation to any known dinoflagellate present in public sequence databases, and branched within the large lineage comprising the short-branching Gymnodiniales, Peridiniales, Dinophysales and Prorocentrales, but with poor support, making it difficult to infer the affinity of Oxytoxum and Corythodinium in the context of these orders. The new sequences branched with peridinioid dinoflagellates such as Heterocapsa and podolampadaceans such as Roscoffia, without support to infer a phylogenetic relationship to the order Peridiniales. Our new sequences did not branch with the long-branching members of the order Gonyaulacales.

\section{Taxonomic considerations}

Molecular data gathered in this study support the separation between the genera Oxytoxum and Corythodinium. The clade of Corythodinium showed a close phylogenetic relationship among its species, such as the relationship between the type species, C. tessellatum (Figs II-L; 2C-H; S1B-C), and other species that largely differed with regard to size, the general appearance, and cell compression and shape such as $C$. cristatum (Figs $1 \mathrm{~N}-\mathrm{O} ; 2 \mathrm{M}-\mathrm{N}$; S1E-F). However, these species maintained diagnostic characteristics of the genus Corythodinium such as the broad cell body, wider epitheca, higher cingular displacement, and an indentation of the sulcus in the epitheca, which is distinct, compared to Oxytoxum. Nonetheless, there are species described under the genus Oxytoxum that have been proposed, prior to the establishment of the genus Corythodinium in 1966; moreover, other species have been described by authors that considered Corythodinium a synonym of Oxytoxum. The next species are candidates to be transferred into Corythodinium: Oxytoxum adriaticum, $O$. areolatum, $O$. brunellii, O. crassum, O. cribrosum, O. criophilum, O. depressum, O. ligusticum, O. milneri, O. minutum, O. mitra, $O$. ovale, O. ovum, O. punctulatum, O. pyramidale, $O$. radiosum, $O$. robustum, $O$. strophalatum and $O$. viride. 

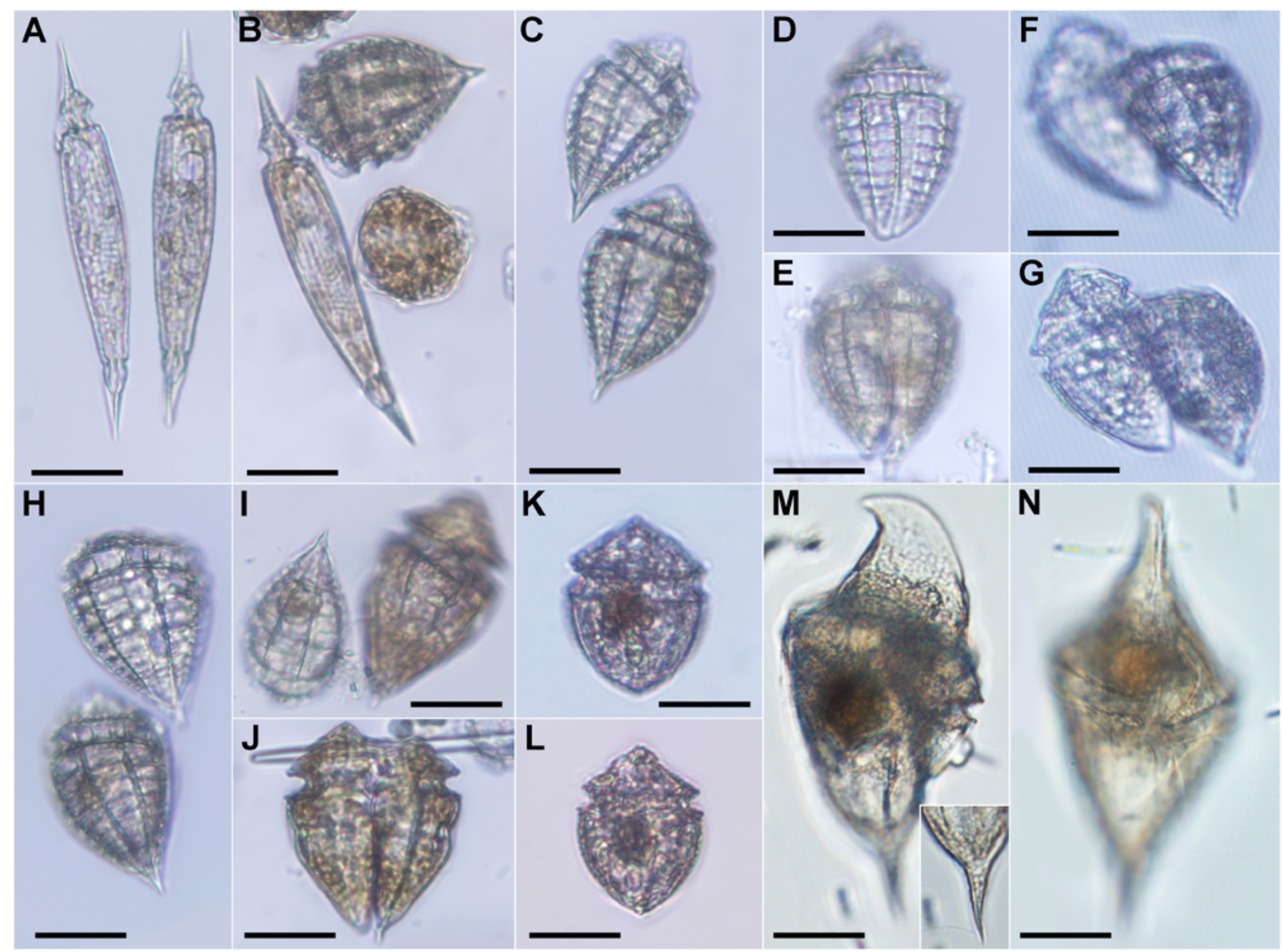

Figs 2A-N. Light micrographs of Oxytoxum and Corythodinium from Brazil. A-Oxytoxum scolopax, isolated cell FG11. B - O. scolopax and C. tessellatum. C-D - C. tessellatum. C - Isolated cell FG9. E-H - Dividing cells of C. tessellatum. H - Isolated cell FG40. I - C. tessellatum and C. constrictum. $\mathbf{J}$ - Diving cells of $C$. constrictum. $\mathbf{K}-\mathbf{L}-$ Corythodinium frenguellii. $\mathbf{K}$ - Isolated cell FG7. $\mathbf{L}-$ Isolated cell FG8. M-N - C. cristatum from the open South Atlantic Ocean, isolated cell FG28. M-The inset focuses on the antapical spine. Scale bars: $20 \mu \mathrm{m}$.

\section{DISCUSSION}

Molecular data largely aided in solving the discrepancies in the relationship between Oxytoxum and Corythodinium, and the classification of the members within the family Oxytoxaceae. Previous classifications have placed Amphidiniopsis, Pseudoadenoides, Roscoffia, Sabulodinium and Thecadinium in the Oxytoxaceae (Loeblich 1982, Dodge 1984, Sournia 1986, Taylor 1987, Chrétiennot-Dinet et al. 1993, Fensome et al. 1993, Steidinger and Tangen 1997). However, the sequences of these genera did not branch within the clade of Oxytoxum and Corythodinium (Fig. 3). Consequently, the family Oxytoxaceae should be restricted to Oxytoxum and Corythodinium that forms their own clade within the dinokaryotic dinoflagellates.

The family Oxytoxaceae is characterized by one antapical plate and five postcingular plates. The first postcingular (1") was shorter and narrower than the others and contacts with the last postcingular plate (5 "') (Stein 1883, Taylor 1976, Dodge and Saunders 1985). The affinities of the Oxytoxaceae and the plate arrangement of peridinioid and gonyaulacoid dinoflagellates have been discussed in Fensome et al. (1993). The family Oxytoxaceae has been placed within the Gonyaulacales (Taylor 1987, Steidinger and Tangen 1997), and authors that do not accept the order Gonyaulacales have placed it between gonyaulacoid genera (Sournia 


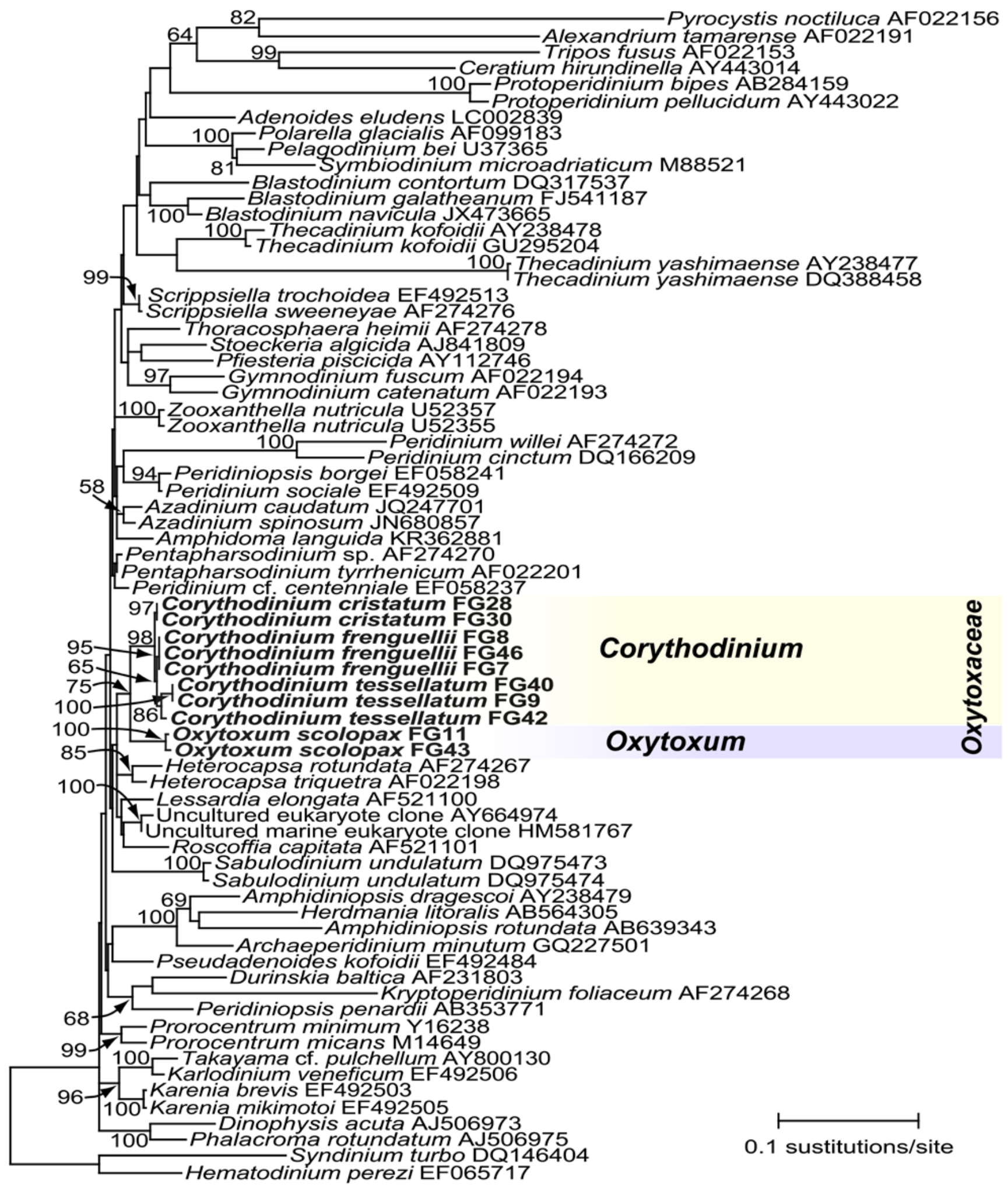

Fig. 3. Maximum Likelihood (ML) phylogenetic tree of Oxytoxum scolopax and Corythodinium spp. with other dinoflagellates inferred from SSU rDNA sequences based on 1,654 aligned positions. The species newly sequenced in this study are highlighted in bold. The numbers at each node represent bootstrap support (only values above $50 \%$ are indicated). The scale bar represents inferred evolutionary distance in substitutions/site. 
1986, Balech 1988). The higher cingular displacement of some species of Corythodinium is reminiscent of the torsion that characterizes gonyaulacoid dinoflagellates. As in most of the gonyaulacoids, the members of the Oxytoxaceae have six precingular plates. However, peridinioid dinoflagellates such as Peridinium and some members of the Diplopsalis-group also possess six precingular plates (Sournia 1986, Steidinger and Tangen 1997). The molecular data does not support any relationship between Oxytoxaceae and gonyaulacoid dinoflagellates that are characterized by long branches in the SSU rDNA phylogenies (Fig. 3). Another characteristic unifying the Oxytoxaceae is the single antapical plate; most dinoflagellates possess two antapical plates (Steidinger and Tangen 1997). In our molecular phylogeny, the Oxytoxaceae branched, without support, as a sister group to Heterocapsa and Roscoffia, the latter a true member of the Podolampadaceae (Gómez et al. 2010a; Fig. 3). A character observed in some members of the Diplopsalis-group and Podolampadaceae, including Roscoffia, is the presence of a single antapical plate (Carbonell-Moore 1994, Steidinger and Tangen 1997).

Within the Oxytoxaceae, the sequences of Corythodinium formed a strongly supported clade. The size and the general appearance (lateral flattening, presence of a crest) of $C$. cristatum (Figs $1 \mathrm{~N}-\mathrm{O} ; 2 \mathrm{M}-\mathrm{N}$ ) was quite different from species such as $C$. tessellatum and C. frenguellii. However, there was little genetic difference between these species. This situation is similar in other genera such as Tripos with species containing significant differences in the cell shape and small genetic differences (Gómez et al. 2010b). This might suggest that a recent speciation event has occurred, resulting in contrasting morphologies and few genetic differences. This study supports the plate arrangement as a diagnostic character for generic split. Still, care should be taken when using general appearance (size, cell shape and compression) as a tool for classification.

Acknowledgements. F.G. was supported by the Ministerio Español de Ciencia y Tecnología (contract number JCI-2010-08492) and the Brazilian Conselho Nacional de Desenvolvimento Científico e Tecnológico (grant number BJT 370646/2013-14). This is a contribution to the ANR Biodiversity program (ANR BDIV 07 004-02 'Aquaparadox'). This work was supported by a Grant-in-Aid for Scientific Research (grant number 253040412 to H.N.) and funds provided to A.Y. from Kobe University, and K.C.W. from the University of Tokyo and the Hokkaido University.

\section{REFERENCES}

Balech E. (1954) Sur la tabulation de Podolampas et Oxytoxum. Rapp. Commun. $8^{e}$ Congr. Int. Bot., sect. 17: 114-116

Balech E. (1971a) Microplancton de la campaña oceanográfica Productividad III. Rev. Mus. Argent. Cienc. Nat. 'B. Rivadavia', Hidrobiol. 3: 1-202

Balech E. (1971b) Microplancton del Atlántico Ecuatorial Oeste (Equalant I). Serv. Hidrogr. Naval, Buenos Aires H. 654: 1-103

Balech E. (1988) Los dinoflagelados del Atlántico Sudoccidental. Pub. Espec. Inst. Español Oceanogr. 1: 1-310

Burns D. A., Mitchell J. S. (1982) Some coastal marine dinoflagellates from around New Zealand. New Zeal. J. Mar. Res. Freshwat. Res. 16: 69-79

Carbonell-Moore M. C. (1994) On the taxonomy of the family Podolampadaceae Lindemann (Dinophyceae) with descriptions of three new genera. Rev. Palaeobot. Palynol. 84: 73-99

Chrétiennot-Dinet M.-J., Sournia A., Ricard M., Billard C. (1993) A classification of the marine phytoplankton of the world from class to genus. Phycologia 32: 159-179

Dodge J. D. (1984) Dinoflagellate Taxonomy. In: Dinoflagellates, (Ed. D. L. Spector). Academic Press, Orlando, Florida, 17-42

Dodge J. D., Saunders R. D. (1985) A partial revision of the genus Oxytoxum (Dinophyceae) with the aid of scanning electron microscopy. Bot. Mar. 28: 99-122

Edgar R. C. (2004) MUSCLE: a multiple sequence alignment method with reduced time and space complexity. BMC Bioinformatics 5: 113

Fensome R. A., Taylor F. J. R., Norris G., Sarjeant W. A. S., Wharton D. I., Williams G. L. (1993) A Classification of Living and Fossil Dinoflagellates. Am. Mus. Nat. Hist. Micropaleontology special publication number 7. Sheridan Press, Hanover, Pennsylvania

Gaarder K. R. (1954) Dinoflagellates from the 'Michael Sars' North Atlantic Deep-Sea Expedition 1910. Rept. Scient. Results 'Michael Sars' N. Atlant. Deep-Sea Exped. 1910, 2: 1-62

Gómez F., Claustre H., Souissi S. (2008) Rarely reported dinoflagellates of the genera Ceratium, Gloeodinium, Histioneis, Oxytoxum and Prorocentrum (Dinophyceae) from the open southeast Pacific Ocean. Rev. Biol. Mar. Oceanogr. 43: 25-40

Gómez F., Moreira D., López-García P. (2010a) Molecular phylogeny of the dinoflagellates Podolampas and Blepharocysta (Peridiniales, Dinophyceae). Phycologia 49: 212-220

Gómez F., Moreira D., López-García P. (2010b) Neoceratium gen. nov., a new genus for all marine species currently assigned to Ceratium (Dinophyceae). Protist 161: 35-54

Gómez F., Qiu D., Dodge J. D., Lopes R. M., Lin S. (2016) Morphological and molecular characterization of Ptychodiscus noctiluca revealed the polyphyletic nature of the order Ptychodiscales (Dinophyceae). J. Phycol. 52: 793-805

Kofoid C. A. (1907) Reports of the scientific results of the expedition to eastern tropical Pacific. IX. New species of dinoflagellates. Bull. Mus. Comp. Zool. Harvard Coll. 50: 162-207

Kofoid C. A., Michener J. R. (1911) New genera and species of dinoflagellates. Bull. Mus. Comp. Zool. Harvard Coll. 54: 267-302

Loeblich A. R. Jr., Loeblich III A. R. (1966) Index to the genera, subgenera, and the sections of the Pyrrhophyta. Stud. Trop. Oceanogr. Miami 3: 1-94

Loeblich A. R. III (1982) Dinophyceae. In: Synopsis and Classification of Living Organisms. Vol. 1, (Ed. S. P. Parker). McGrawHill, New York, 101-115

Murray G., Whitting F. (1899) New Peridiniaceae from the Atlantic. Trans. Linn. Soc. London, $2^{\text {nd }}$ ser., Bot. 5: 321-342 
Rampi L. (1939) Su qualche Peridinea rara, nuova o curiosa nel fitoplancton del mare Ligure. Nuovo Giorn. Bot. Ital. n. ser. 46: 456-469

Rampi L. (1941) Ricerche sul fitoplancton del mare Ligure 3. Le Heterodiniacee e le Oxytoxacee delle acque di Sanremo. Ann. Mus. Civico Storia Nat. Genova 61: 50-69

Rampi L. (1951) Su alcune Peridinee nuove od interesanti raccolte nelle acque di San-remo. Atti Accademia Ligure Scienze e Lettere 8: $1-11$

Schiller J. (1937) Dinoflagellatae (Peridineae) in monographischer Behandlung. In: Kryptogamen-Flora von Deutschland, Österreichs und der Schweiz. Vol. 2, (Ed. L. Rabenhorst). Akad. Verlag, Leipzig, 1-589

Sournia A. (1986) Atlas du Phytoplancton Marin. Vol. I: Introduction, Cyanophycées, Dictyochophycées, Dinophycées et Raphidophycées. CNRS, Paris
Steidinger K. A., Tangen K. (1997) Dinoflagellates. In: Identifying Marine Phytoplankton, (Ed. C. Tomas). Academic Press, San Diego, USA, 387-584

Stein F. (1883) Der Organisms der Infusionsthiere. III. Flagellaten II. W. Engelmann, Leipzig.

Taylor F. J. R. (1976) Dinoflagellates from the International Indian Ocean Expedition. Bibl. Bot. 132: 1-234

Taylor F. J. R. (1987) Taxonomy and classification. In: The Biology of Dinoflagellates, (Ed. F. J. R. Taylor). Botanical Monographs 21. Blackwell, Oxford, U.K., 723-731

Received on $19^{\text {th }}$ September, 2016; revised on $24^{\text {th }}$ November, 2016; accepted on $16^{\text {th }}$ December, 2016

\section{SUPPORTING INFORMATION}

Appendix S1. Methods of sampling and observations in the Mediterranean Sea

\section{Sampling, isolation and light microscopy}

Specimens were collected from the Mediterranean Sea by slowly filtering surface seawater taken from the pier of the Station Marine d'Endoume at Marseille, France $\left(43^{\circ} 16^{\prime} 48.05^{\prime \prime} \mathrm{N}, 5^{\circ} 20^{\prime} 56.22^{\prime \prime} \mathrm{E}\right.$, bottom depth 3 m) from October 2007 to September 2008. A strainer of 20,40 , or $60-\mu \mathrm{m}$ mesh size was used to collect planktonic organisms from water volumes ranging between 10 and 1001 , depending on particle concentration. The plankton concentrate was scanned in settling chambers at $\times 100$ magnification with an inverted microscope (Nikon Eclipse TE200; Nikon Inc., Tokyo, Japan). Cells were photographed alive at $\times 200$ or $\times 400$ magnifications with a Nikon Coolpix E995 digital camera. Further specimens were collected using the same method from October 2008 to August 2009 in the surface waters (depth of $2 \mathrm{~m}$ ) of the port of Banyuls sur Mer, France $\left(42^{\circ} 28^{\prime} 50^{\prime \prime} \mathrm{N}, 3^{\circ} 08^{\prime} 09^{\prime \prime} \mathrm{E}\right)$. The concentrated sample was examined in Utermöhl chambers with an inverted epifluorescence microscope (Olympus IX51; Olympus Inc., Tokyo, Japan) and photographed with an Olympus DP71 digital camera. Sampling continued from September 2009 to February 2010 in the Bay of Villefranche sur Mer, France. For this location, sampling was performed at the long-term monitoring site Point B $\left(43^{\circ} 41^{\prime} 10^{\prime \prime} \mathrm{N}, 7^{\circ} 19^{\prime} 00^{\prime \prime} \mathrm{E}\right.$, water column depth $\sim 80 \mathrm{~m})$. Water column samples $(0-80 \mathrm{~m})$ were obtained using a phytoplankton net $(53 \mu \mathrm{m}$ mesh size, $54 \mathrm{~cm}$ diameter, $280 \mathrm{~cm}$ length). Samples were prepared according to the same procedure as described above and specimens were observed with an inverted microscope
(Olympus IX51, Olympus Inc.) and photographed with an Olympus DP71 digital camera. Sampling continued from May 2012 to February 2013 in the port of Valencia, Spain $\left(39^{\circ} 27^{\prime} 38.13^{\prime \prime} \mathrm{N}, 0^{\circ} 19^{\prime} 21.29^{\prime \prime} \mathrm{W}\right.$, water column depth of $4 \mathrm{~m}$ ). Specimens were obtained using a phytoplankton net (20 $\mu \mathrm{m}$ mesh size). Samples were prepared according to the same procedure as described above and specimens were observed with an inverted microscope (Nikon Eclipse T2000; Nikon Inc.) and photographed with an Olympus DP71 digital camera.

In addition, samples were collected during the BOUM (Biogeochemistry from the Oligotrophic to the Ultra-oligotrophic Mediterranean) cruise on board R/V $L$ 'Atalante from the south of France to the south of $\mathrm{Cy}$ prus (20 June-18 July 2008). Seawater samples were collected with Niskin bottles from 30 stations. At each station 6 depths were sampled between 5 and $125 \mathrm{~m}$, with an additional sample at $250 \mathrm{~m}$ depth. These samples were preserved with acid Lugol's iodine and stored at $5^{\circ} \mathrm{C}$. Samples of $500 \mathrm{ml}$ were concentrated via sedimentation in glass cylinders. The top $450 \mathrm{ml}$ of sample was slowly siphoned off with small-bore tubing during 6 days. The remaining $50 \mathrm{ml}$ of concentrate, representing $500 \mathrm{ml}$ whole water, was then settled in composite settling chambers. The sample was examined in Utermöhl chambers at $\times 100$ magnification with a Nikon inverted microscope (Nikon Eclipse TE200) and the specimens were photographed with a digital camera (Nikon Coolpix E995). 
248 F. Gómez et al.

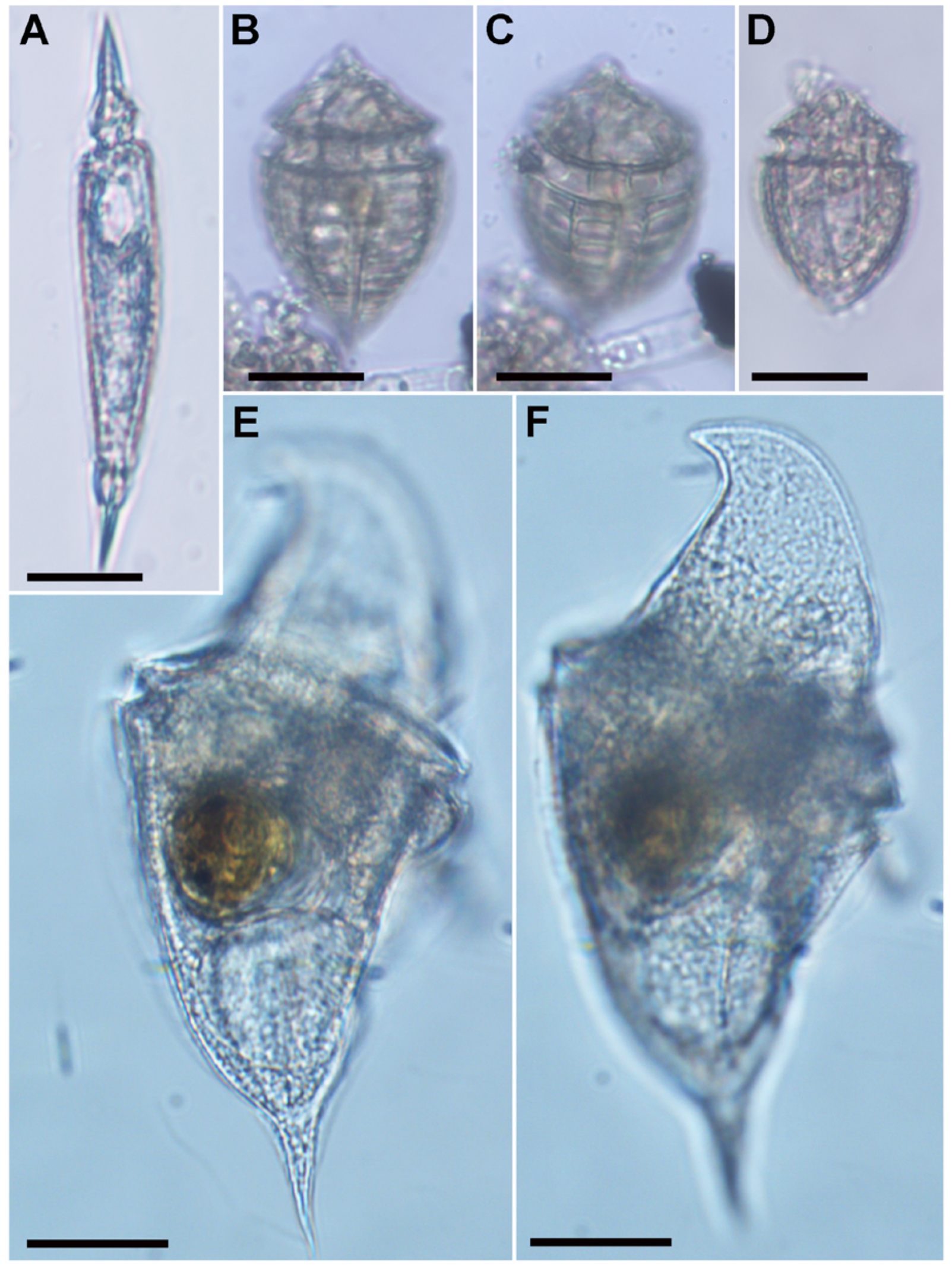

Figure S1. Light micrographs of isolated cells of Oxytoxum and Corythodinium for molecular analysis. 